\title{
Effects of Some Extraction Solvents on the Antioxidant Properties of Strawberry Fruit
}

\author{
Nagihan M. Karaaslan ${ }^{1 *}$, Merve Goksin Karaaslan ${ }^{2}$ Burhan Ates $^{2}$ \\ I*Department of Chemical Engineering, Faculty of Engineering, Munzur University, Tunceli, Turkey, \\ nkaraaslan@munzur.edu.tr \\ ${ }^{2}$ Department of Chemistry, Faculty of Arts and Sciences, Inonu University, 44280 Malatya, Turkey, \\ mgkaraaslan@gmail.com,burhan.ates@inonu.edu.tr \\ Received date: 17.11.2017, Accepted date: 22.11.2018
}

\begin{abstract}
In this paper, antioxidant activity of strawberries extracted with different solvents was investigated since they are consumed by people due to their anticancer, anti-atherosclerotic, anti-inflammatory and anti-neurodegenerative properties. For this purpose, different acidified extraction solvents such as water (ES1), acetone (ES2), acetonitrile (ES3), methanol (ES4) and ethanol (ES5) were used in extraction process of strawberries. The effects of different extraction solvents on the antioxidant activity were evaluated by measuring the reducing power, 2,2'-azino-bis(3ethylbenzothiazoline-6-sulfonic acid (ABTS) radical scavenging activity, 1,1-diphenyl-2-picrylhydrazyl (DPPH) radical scavenging activity, total flavonoid content (TFC) and total phenolic content (TPC). Experimental results indicated that the obtained data varied with different extraction solvents. All antioxidant activity assay results showed that the highest results were obtained with acetone extracts.
\end{abstract}

Keywords: Antioxidant activity, extraction solvent, strawberry

\section{Çilek Meyvesinin Antioksidan Özellikleri Üzerine Bazı Ekstraksiyon Solventlerinin Etkileri}

\section{Öz}

$\mathrm{Bu}$ makalede, antikanser, anti-aterosklerotik, anti-enflamatuar ve anti-nörodejeneratif özelliklerinden dolay1 insanlar tarafindan tüketilen çileklerin farklı ekstraksiyon çözücülerindeki antioksidan aktiviteleri araştırılmıştır. Bu amaç için, çileklerin ekstraksiyon işleminde su (ES1), aseton (ES2), asetonitril (ES3), metanol (ES4) ve etanol (ES5) gibi farklı asitlendirilmiş ekstraksiyon çözücüleri kullanılmıştır. Antioksidan aktiviteye farklı ekstraksiyon çözücülerinin etkileri indirme gücü, 2,2'-azino-bis (3-etilbenzotiazolin-6-sülfonik asit (ABTS) radikal süpürme aktivite, 1,1-difenil-2-pikrilhidrazil (DPPH) radikal süpürme aktivite, toplam flavonoid içerik (TFC) ve toplam fenolik içerik (TPC) analizleri kullanılarak değerlendirilmiştir. Deneysel sonuçlar elde edilen dataların farklı ekstraksiyon çözücüleri ile değiştiğini göstermiştir. Tüm antioksidan aktivite analiz sonuçları, en yüksek sonuçların asetonlu ekstraklardan elde edildiğini göstermiştir.

Anahtar Kelimeler: Antioksidan aktivite, ekstraksiyon çözücüsü, çilek

\section{INTRODUCTION}

Consuming vegetables and fruits is important to lower the risk of a number of chronic diseases and is useful in preventing immune dysfunction (Bazzano, 2005; WCRF/AICR, 2007). They also provide life sustaining nutrients containing a diversity of phytochemicals together with phenolic, flavonoids, minerals and vitamins (Peterson and Dwyer, 1998). Strawberry is a beneficial fruit in terms of its nutritional and health benefits (Ubeda, 2013). Strawberries contain potentially bioactive compounds and are rich in polyphenols including flavonoids and phenolic acids such as antiviral, antiinflammatory, antiallergic, anti-aging and anticarcinogenic properties ascribed to their antioxidant properties (Aaby et al., 2005; Seeram et al., 2006). Polyphenols have a prominence preventing oxidative processes caused by reactive oxygen species (ROS) (Aaby et al., 2005; Cerezo et al., 2010). Strawberry has highly antioxidant properties because of these compounds (Wolfe et al., 2008).

The extraction procedure is important in the determination of polyphenols in fruits and how polyphenols can be transferred to the extracts (Mitic 
et al., 2014). In addition, it is also essential in the determination of antioxidant activity in fruits (Santas et al., 2008). Solvent extraction of polyphenols usually involves the use of an acidified medium (Mitic et al., 2014). The yield and antioxidant activities of natural extracts such as fruits, plants, etc. change depending on different extraction solvents (Boulekbache-Makhlouf et al., 2013). Hayouni et al. (2007) emphasize the use of extraction solvents such as aqueous mixtures of methanol, ethanol and acetone. For instance, Wang and Helliwell (2001) reported that aqueous ethanol was a better extraction solvent than methanol and acetone in getting flavonoids from tea leaves. For this reason, the extraction yield can change from one extraction solvent to another, and so the ideal extraction method should be developed and optimized for particular phenolic classes (Boulekbache-Makhlouf et al., 2013). The solvent type, one of the most important parameters in the extraction procedure, needs to be investigated.

The main objective of this study was to investigate the effect of extraction solvents in the determination of antioxidant activity of strawberries. For this purpose, these berries were extracted by using five acidified extraction solvents, namely water (ES1), acetone (ES2), acetonitrile (ES3), methanol (ES4) and ethanol (ES5) and these extracts were analyzed using UV-Vis spectrophotometry.

\section{MATERIAL AND METHOD \\ Reagents and Standards}

Acetic acid, acetone, acetonitrile, ethanol, methanol, hydrochloric acid, aluminum chloride, folin-ciocalteu reagent, gallic acid, iron (III) chloride hexahydrate, potassium ferricyanide, potassium peroxodisulfate, quercetin, sodium carbonate, sodium hydroxide, sodium nitrite, sodium hydrogen phosphate, bisodium hydrogen phosphate, trichloroacetic acid (TCA), 2,2'-azino-bis(3ethylbenzothiazoline-6-sulfonic acid (ABTS), 1,1diphenyl-2-picrylhydrazyl (DPPH), ( \pm )-6-hydroxy2,5,7,8-tetramethylchromane-2-carboxylic acid (trolox) were purchased from Merck and Sigma Aldrich. Both chemicals and solvents were of analytical grade. Ultra-pure water was provided by Millipore Direct Q.

Stock standard solutions (1000 $\left.\mathrm{mg} \mathrm{L}^{-1}\right)$ were prepared for antioxidant activity assays and these solutions were used to prepare standard solutions at different concentrations. Calibration graphs were established using standard solutions and by means of these graphs linear regression equations were calculated. A Shimadzu 1601 UV-Vis spectrophotometer (Tokyo, Japan) was used for all measurements.

\section{Sample Preparation Procedure}

Strawberries, grown in the Elazig city of Turkey where they contribute to the city economy, were purchased from different local markets in this city. After washing with tap water and ultra-pure water, they were put in plastic bags and preserved in darkness in a freezer until the time of analysis.

Deep-frozen strawberries were thawed and a homogeneous mixture was prepared with a domestic blender. Three samples of about five grams $(5 \mathrm{~g})$ of strawberries were prepared and these samples were extracted at room temperature for 1 hour using 10 $\mathrm{mL}$ of different extraction solvents (water, acetone, acetonitrile, methanol and ethanol) which were acidified with $0.1 \% \mathrm{HCl}$. Then each extract was centrifuged at $4000 \mathrm{rpm}$ for $10 \mathrm{~min}$, supernatants were carefully collected and filtered. Antioxidant activity assays were applied to all the extracts. The measurements were carried out with a UV-Vis spectrophotometer.

For the determination of antioxidant activity of strawberries different antioxidant activity assays were conducted using procedures shown in related literature. Reducing power assay applied by Oyaizu (1988), ABTS radical scavenging activity assay applied by Re et al. (1999), DPPH radical scavenging activity assay applied by BrandWilliams et al. (1995), TFC applied by Zhishen et al. (1999) and TPC applied by Singleton and Rossi (1965) were modified and applied to different strawberry extracts in the current study. To perform the reducing power assay, the extracts $(25 \mu \mathrm{L})$ were mixed with $0.2 \mathrm{M}$ of phosphate buffer $(\mathrm{pH} \mathrm{6.6)}$ and $1 \%$ potassium ferricyanide solution. These mixtures were incubated in a water bath $\left(50^{\circ} \mathrm{C}, 20 \mathrm{~min}\right)$. After incubation, $10 \%$ TCA was added and centrifuged (6000 rpm, $10 \mathrm{~min}$ ), then ultra-pure water and $0.1 \%$ iron (III) chloride were added to the supernatant. After 5 min incubation, the solutions' absorbance was determined at $700 \mathrm{~nm}$. To perform the ABTS radical scavenging capacity assay, ABTS $\bullet+$ stock solution was added to the extracts $(50 \mu \mathrm{L}$ of twentyfold diluted extract) for a total of $2.5 \mathrm{~mL}$, incubated $30 \mathrm{~min}$ at room temperature and the solutions' absorbance was measured at $734 \mathrm{~nm}$. As 
for the DPPH radical scavenging capacity assay, to the sample volume $(50 \mu \mathrm{L}$ of fivefold diluted extract) DPPH solution was added to make a total volume of $2.5 \mathrm{~mL}$ and incubated at room temperature for $30 \mathrm{~min}$. After the incubation step, the solutions' absorbance was determined at $517 \mathrm{~nm}$. For the TFC assay, 5\% sodium nitrite solution, 10\% aluminum chloride, $1 \mathrm{M}$ sodium hydroxide $(500 \mu \mathrm{L})$ were added to the extracts and the mixtures' absorbance was detected at $510 \mathrm{~nm}$. As for the TPC assay, Folin-Ciocalteu reactant and $2 \%$ sodium carbonate solution were added to the extracts $(50 \mu \mathrm{L}$ of fivefold diluted extract). The mixtures' absorbance was measured at $755 \mathrm{~nm}$ after incubation $\left(25^{\circ} \mathrm{C}, 30 \mathrm{~min}\right)$. The experimental results were calculated as mg Trolox equivalent (TEAC) $100 \mathrm{~g}^{-1}$ strawberry for reducing power, ABTS radical scavenging activity, DPPH radical scavenging activity. The data were calculated as mg quercetin equivalent (QE) $100 \mathrm{~g}^{-1}$ strawberry for TFC and $\mathrm{mg}$ gallic acid equivalent (GAE) $100 \mathrm{~g}^{-1}$ strawberry for TPC. The experimental results were expressed in terms of fresh weight (FW).

\section{Statistical Analysis}

GraphPad Software (version 5.01 for Windows, GraphPad Software, USA) was used to evaluate the experimental data statistically. The significance between the groups was determined using the oneway analysis of variance (ANOVA) and Tukey's multiple comparison tests. The data were shown as the mean values \pm standard deviation on fresh weight basis. Each column was evaluated within itself and mean values of different letters were significantly different from each other $(\mathrm{p}<0.05)$.

\section{RESULTS AND DISCUSSION}

The antioxidant activity of plant extracts cannot be assessed by adopting only one method owing to the complex nature of phytochemicals (Marioda et al., 2012). Therefore, more than one method described in literature can be performed in determining antioxidant activity. DPPH radical scavenging capacity assay is commonly utilized in order to examine the free radical scavenging ability of various food components (Dorman and Hiltunen, 2004). Free radical scavenging is the basic mechanism of action of phenolic antioxidants (Reis et al., 2010). As for ABTS radical scavenging assay is carried out to study the free radical scavenging ability. This method is most widespread and an easy assay for the fast estimation of antioxidant activity (Prior et al., 2005). In the determination of antioxidant activity, DPPH and ABTS both provide consistent results (Sun and Ho, 2005). As a result of these, DPPH and ABTS can be selected to determine the best extraction parameters.

In the present study, ES1, ES2, ES3, ES4 and ES5 solvents were used for extraction of strawberries. The reducing power, ABTS radical scavenging activity, DPPH radical scavenging activity, TFC and TPC assays were conducted for the determination of antioxidant properties for different extracts of this fruit. The experimental data were evaluated statistically and demonstrated that the results varied depending on extraction solvents. While the extraction with ES2 solvent presented the highest results in all assays, the extraction with ESI solvent presented the lowest in all assays except in one test (TFC). Figure 1-5 show the results of the reducing power, ABTS radical scavenging activity, DPPH radical scavenging activity, TFC and TPC using different solvents, respectively.

As shown in Figure 1, when the mean values of the different extraction solvents of the reducing power were compared, the experimental data ranged from $286.5 \pm 19.3$ to $545.2 \pm 12.5 \mathrm{mg}$ TEAC $100 \mathrm{~g}^{-1}$ FW. According to the obtained results, the reducing power mean values were found as mg TEAC $100 \mathrm{~g}^{-1}$ FW ES2 $(545.2 \pm 12.5)>E S 5(495.7 \pm 23.8)>E S 4$ $(444.9 \pm 26.8)>E S 3 \quad(401.9 \pm 15.7)>E S 1$ (286.5 \pm 19.3$)$, respectively. When the experimental results for reducing power were compared statistically, it was found that there was a statistically significant difference between each two extracts except for ES3 and ES4 (p<0.05).

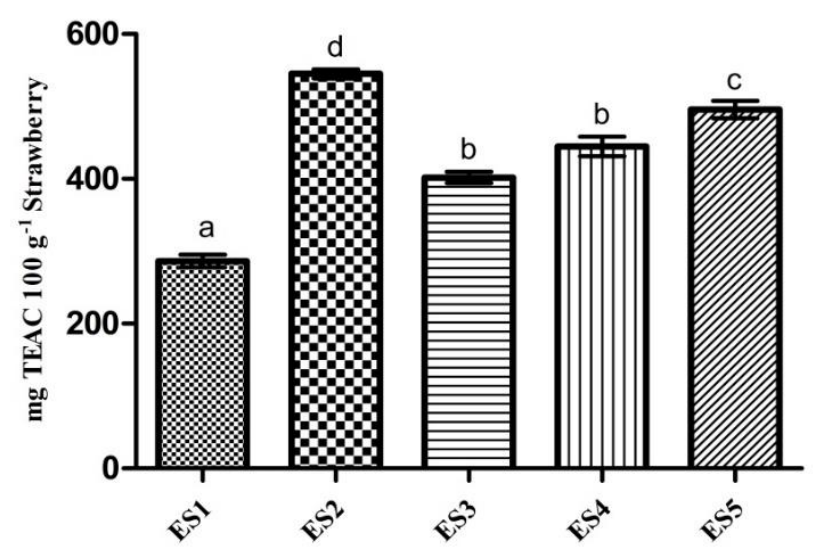

Figure 1. Reducing power of strawberry extracts obtained by different extraction solvents 
When the mean values were examined for different extraction solvents in ABTS radical scavenging activity assay, the highest and lowest values were found in $E S 2$ extract as $827.7 \pm 19.1 \mathrm{mg}$ TEAC $100 \mathrm{~g}^{-1} \mathrm{FW}$ and in $E S 1$ extracts as $405.9 \pm 10.5$ mg TEAC $100 \mathrm{~g}^{-1} \mathrm{FW}$, respectively (see Figure 2). The experimental mean values were measured as $\mathrm{mg}$ TEAC $100 \mathrm{~g}^{-1} \mathrm{FW}$ for each extracts; $405.9 \pm 10.5$ for $E S 1, \quad 827.7 \pm 19.1$ for $E S 2,669.6 \pm 6.2$ for $E S 3$, $672.8 \pm 41.1$ for $E S 4$ and $777.9 \pm 49.5$ for ES5. When the experimental results for ABTS radical scavenging were compared statistically, it was found that there was a statistically significant difference between each two extracts except for ES2 and ES5; $E S 3$ and $E S 4(\mathrm{p}<0.05)$.

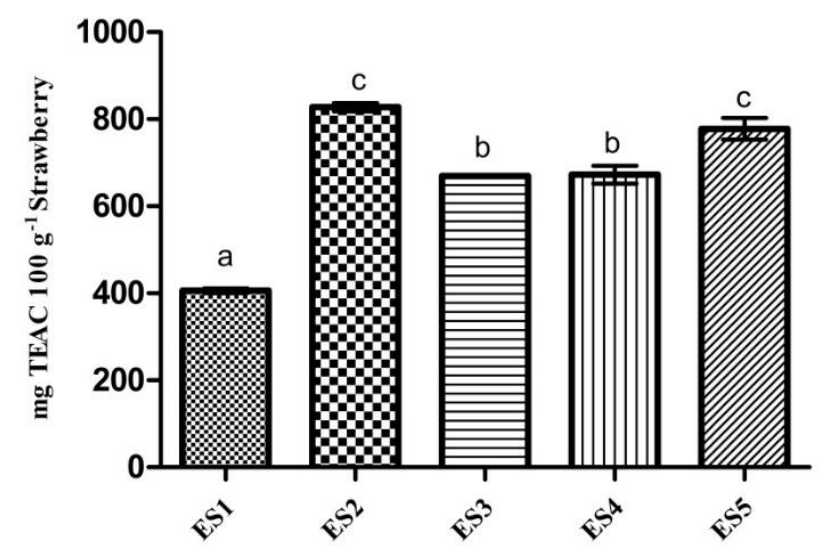

Figure 2. ABTS radical scavenging activity of strawberry extracts obtained by different extraction solvents

In Figure 3, when the mean values of the different extraction solvents of the DPPH radical scavenging activity assay were compared, the experimental data varied from $254.0 \pm 1.7$ to $357.1 \pm 8.28 \mathrm{mg}$ TEAC $100 \mathrm{~g}^{-1} \mathrm{FW}$. DPPH radical scavenging activity mean values were observed as mg TEAC $100 \mathrm{~g}^{-1} \mathrm{FW}$ ES2 $(357.1 \pm 8.28)>E S 3$ $(356.0 \pm 1.0)>\operatorname{ES} 4(355.6 \pm 5.9)>\operatorname{ES} 5(344.6 \pm 3.9)>$

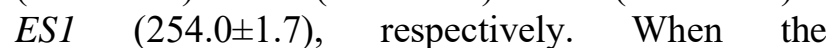
experimental results for DPPH radical scavenging activity were compared statistically, it was found that there was a statistically significant difference between each two extracts except for ES2 and ES3; $E S 2$ and ES4; ES3 and ES4 (p<0.05).

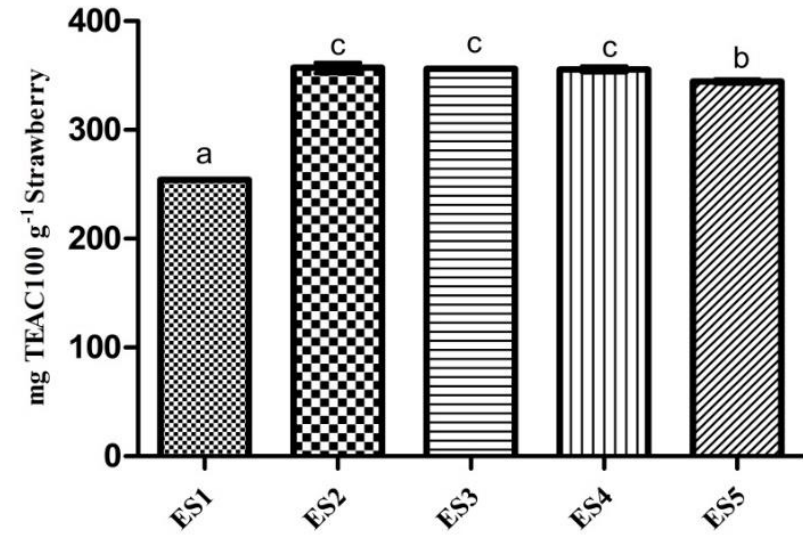

Figure 3. DPPH radical scavenging activity of strawberry extracts obtained by different extraction solvents

The mean values of the different extraction solvents for the total flavonoid content were given in Figure 4. This figure indicated that while the highest value was $E S 2$ as $112.3 \pm 4.2 \mathrm{mg}$ QE $100 \mathrm{~g}^{-1} \mathrm{FW}$, the lowest value was ES4 as $36.2 \pm 2.5 \mathrm{mg}$ QE $100 \mathrm{~g}^{-1}$ FW. For this test, the mean values as mg QE $100 \mathrm{~g}^{-1}$ FW $38.4 \pm 1.8 ; 112.3 \pm 4.2 ; 111.7 \pm 6.6 ; 36.2 \pm 2.5$ and $38.3 \pm 1.9$ were determined ES1, ES2, ES3, ES4 and ES5 for each extracts, respectively. When the experimental results for total flavonoid content were compared statistically, it was found that there was a statistically significant difference between each two extracts except for ES1 and ES4; ES1 and ES5; ES2 and $E S 3 ; E S 4$ and $E S 5$ ( $<<0.05)$.

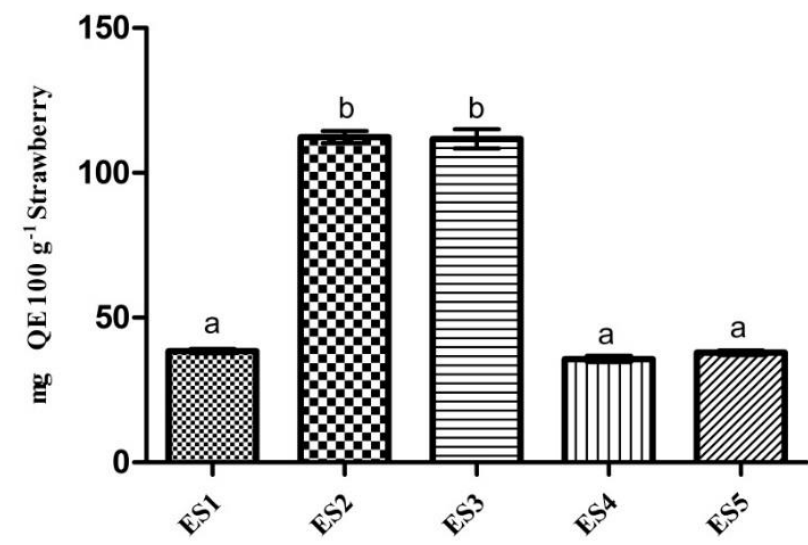

Figure 4. Total flavonoid content of strawberry extracts obtained by different extraction solvents 
When the mean values of the different extraction solvents of total phenolic content (Figure 5 ) were evaluated, the experimental data varied from $75.4 \pm 3.5$ to $121.2 \pm 2.1 \mathrm{mg}$ GAE $100 \mathrm{~g}^{-1} \mathrm{FW}$. The mean values for different extraction solvents for TPC were found as mg GAE $100 \mathrm{~g}^{-1} \mathrm{FW} 121.2 \pm 2.1$ for $E S 2,112.5 \pm 3.3$ for $E S 5,107.6 \pm 3.9$ for $E S 3$, $105.3 \pm 2.3$ for $E S 4,75.4 \pm 3.5$ for $E S 1$, respectively. When the experimental results for total phenolic content were compared statistically, it was found that there was a statistically significant difference between each two solvents except for ES3 and ES4; $E S 3$ and ES5 (p<0.05).

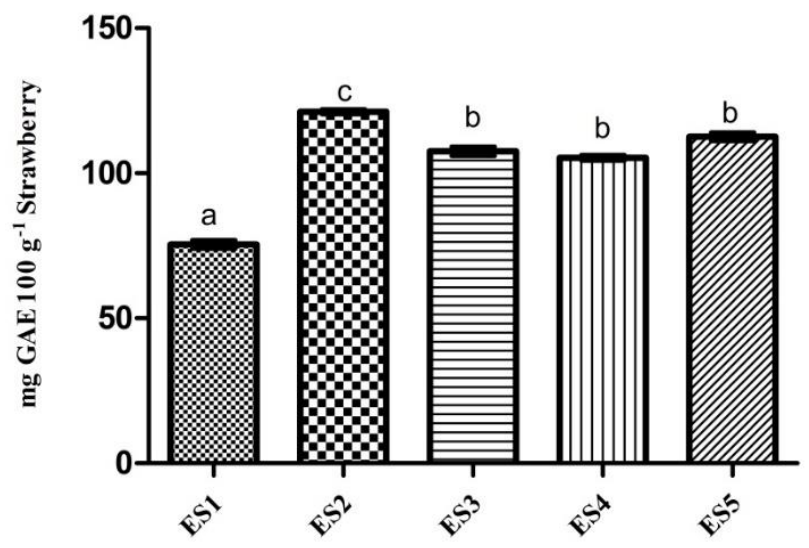

Figure 5. Total phenolic content of strawberry extracts obtained by different extraction solvents

Kim and Shin (2015) studied antioxidant properties of strawberries from different cultivars and harvest locations. In their research, the mean flavonoid concentrations were found as 524.3, $522.4,512.1 \mathrm{mg} \mathrm{kg}^{-1} \mathrm{FW}$ and the mean phenolic concentrations were identified as 1960.3, 1819.2, $1992.6 \mathrm{mg} \mathrm{kg}^{-1} \mathrm{FW}$ from three major strawberry cultivars named 'Yukbo,' 'Seolhyang,' and 'Janghee', three different locations, respectively. In our study, TFC mean values ranged from $36.2 \pm 2.5$ to $112.3 \pm 4.2 \mathrm{mg}$ QE $100 \mathrm{~g}^{-1} \mathrm{FW}$ in different extraction solvents and TPC mean values varied from $75.4 \pm 3.5$ to $121.2 \pm 2.1 \mathrm{mg}$ GAE $100 \mathrm{~g}^{-1} \mathrm{FW}$. The values obtained in our study were higher than in the above study in terms of TFC values, as for the TPC values, our study values were found to be lower. In addition, Kim and Shin (2015) also studied DPPH radical scavenging activity in these strawberry species and mean DPPH radical scavenging activity values were found to be 1.175 , 2.118, $2.199 \mathrm{~g} \mathrm{~kg}^{-1} \mathrm{FW}$ from three different locations respectively. Our study revealed that the DPPH radical scavenging activity values ranged from 254.0 $\pm 1.7-357.1 \pm 8.28 \mathrm{mg}$ TEAC to $100 \mathrm{~g}^{-1}$ FW, and relatively high results were obtained compared to their study. While they prepared samples with only one extraction solvent, our study performed all assays with five different extraction solvents. Meanwhile, it was seen that the experimental data results change with changing extraction solvents for all assays. Wang and Lin (2000) investigated antioxidant activity fruits and leaves such as strawberry, blackberry and raspberry and found that data varies with cultivar and developmental stage. While the TPC values harvested at a red ripe stage varied from 950 to 1520 $\mathrm{mg} \mathrm{kg}^{-1} \mathrm{FW}$ which was higher than in our results (in our study ranging from $75.4 \pm 3.5$ to $121.2 \pm 2.1 \mathrm{mg}$ GAE $100 \mathrm{~g}^{-1} \mathrm{FW}$ ). This difference might be due to the climatic conditions, the soil type and the ripening period of the fruit. Dyduch-Sieminska et al. (2015) explored the contents of flavonoids, free phenolic acids, tannins, anthocyanins, and antioxidant activity by means of DPPH radical neutralization ability in fruits of three wild strawberry cultivars. For three fresh wild strawberry cultivars, the TFC and TPC mean values were found to be $0.530 \mathrm{mg} \mathrm{g}^{-1}$ (as quercetin) and $2.314 \mathrm{mg} \mathrm{g}^{-1}$ (as caffeic acid), respectively. It was found that the TFC content was compatible with our study, and that some extracts were higher in our study. TPC values were found to be low in our study.

Mitic et al. (2014) used extraction solutions (80\% methanol, ethanol, and acetone) containing $0.1 \% \mathrm{HCl}$ to evaluate and characterized the phenolic composition and antioxidant activities of wild and cultivated strawberries. The maximum quantity of total phenolic was obtained in acetone extracts (ranging from $14.93 \pm 0.28$ to $20.38 \pm 0.32 \mathrm{mg} \mathrm{GAE} \mathrm{g}$ ${ }^{1}$ dried fruit) and the minimum quantity was obtained in methanol extracts (ranging from $9.59 \pm 0.30$ to

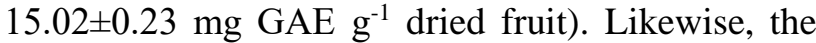
highest amount of total flavonoids was found in acetone extracts (ranged from $7.97 \pm 0.18$ to $13.28 \pm 0.38 \mathrm{mg} \mathrm{CE} \mathrm{g}^{-1}$ dried fruit) and the lowest one was determined in methanol extracts (ranged from $3.39 \pm 0.18$ to $6.93 \pm 0.18 \mathrm{mg} \mathrm{CE} \mathrm{g}^{-1}$ dried fruit). In acetone extracts, highest antioxidant capacity (DPPH radical scavenging activity) was observed ranging from $89.35 \pm 2.09$ to $116.13 \pm 1.82 \mu \mathrm{mol} \mathrm{TE} \mathrm{g}^{-}$ ${ }^{1}$ dried fruit and in methanol extracts, the lowest antioxidant capacity was perceived ranging from 
$52.69 \pm 1.69$ to $82.85 \pm 2.03 \mu \mathrm{mol} \mathrm{TE} \mathrm{g}^{-1}$ dried fruit. As for the present study, the highest TPC, TFC and DPPH radical scavenging activity mean values were obtained for $E S 2$ extracts (121.2 $\pm 2.1 \mathrm{mg}$ GAE $100 \mathrm{~g}$ $\left.{ }^{1} \mathrm{FW}\right)$, ES2 extracts $\left(112.3 \pm 4.2 \mathrm{mg}\right.$ QE $\left.100 \mathrm{~g}^{-1} \mathrm{FW}\right)$ and ES2 extracts $\left(357.1 \pm 8.28 \mathrm{mg}\right.$ TEAC $100 \mathrm{~g}^{-1}$ FW), respectively. The lowest TPC, TFC and DPPH radical scavenging activity mean values were obtained with ES1 extracts (75.4 $\pm 3.5 \mathrm{mg}$ GAE 100 $\left.\mathrm{g}^{-1} \mathrm{FW}\right)$, ES4 extracts $\left(36.2 \pm 2.5 \mathrm{mg}\right.$ QE $\left.100 \mathrm{~g}^{-1} \mathrm{FW}\right)$ and ESI extracts $\left(254.0 \pm 1.7 \mathrm{mg}^{\mathrm{TEAC}} \mathrm{g}^{-1} \mathrm{FW}\right)$. Both the current study and Mitic et al. (2014) studies indicated that the effect of extraction solvents have an influence on the determination of antioxidant activity of this type of fruits and it was perceived that experimental data changes depended on the type of the extraction solvents.

Boulekbache-Makhlouf et al. (2013) investigated the effect of solvents extraction on antioxidant properties of the byproduct (peel) of eggplant. Similar to the present study, they examined the antioxidant activities using three different solvents $(70 \%$ methanol, ethanol, and acetone). Their study also revealed that the type of solvent extracts affects the experimental results. As in our study, the highest results for TFC and TPC have been obtained in acetone extracts. Saini et al. (2013) evaluated antioxidant properties in four different solvent systems specifically $80 \%$ methanol, acidic-methanol, acetone, and acidic-acetone. When the antioxidant test results were examined (TPC, TFC, DPPH radical scavenging activity, ABTS radical scavenging activity), the highest results in all assays were obtained in acidic acetone extracts. In general, it has been observed that acetone extracts give higher results than methanol extracts and the acidity of the solvents affected the results. In our study, all solvents were acidified and the highest results for all assays were obtained with acidified acetone extracts. Seal et al. (2015) studied effects of solvents to evaluate the antioxidant activities of five algae. They carried out antioxidant activity tests using benzene, chloroform, acetone and methanol in the extraction procedure. Total phenolic content, total flavonoid content, total flavonol content, reducing power and DPPH radical scavenging activity assays were applied to the extracts obtained. When the data was examined in detail, the related results changed depending on the type of the extract solvents. Consequently, it was seen that it is important to investigate the extraction solvent in antioxidant activity assays and that it has an effect on the results.

In this study, the effects of different extraction solvents on the antioxidant activity of strawberries were evaluated using antioxidant activity assays. The experimental results were changed depending on the use of different solvents. The reason of the difference between the current and previous studies results can be caused by climatic factors, soil content, temperature, and light and also might be caused by utilization of different extraction methods. To sum up, the results reported by literature and the present study demonstrated that the type of extraction solvents had a crucial effect in antioxidant activity assays. Therefore, for similar studies the extraction methods should be carefully designed and examined.

\section{CONCLUSION}

Antioxidant activities of strawberries grown in the Elazig city of Turkey were investigated in different extraction solvents. The effect of different extraction solvents on the antioxidant activity was evaluated by measuring reducing power, ABTS radical scavenging activity, DPPH radical scavenging activity, TFC and TPC. Experimental results indicated that the obtained results varied with changing extraction solvents. While the extraction with ES2 solvent (acetone) presented the highest results in all assays, the extraction with ES1 solvent (water) presented the lowest in all assays except in one test (TFC). As a result, it can be stated that it is important to investigate the type of extraction solvent in antioxidant activity assays.

\section{REFERENCES}

Aaby, K., Skrede, G., Wrolstad, R.E., 2005. Phenolic composition and antioxidant activities in flesh and achenes of strawberries (Fragaria ananassa). Journal of Agricultural and Food Chemistry, 53(10):4032-4040.

Bazzano, L.A., 2005. Dietary intake of fruit and vegetables and risk of diabetes mellitus and cardiovascular diseases, In: Background Paper of the Joint FAO/WHO Workshop on Fruit and Vegetables for Health. World Health Organization, Kobe, Japan, $1-65$.

Boulekbache-Makhlouf, L., Medouni, L., MedouniAdrar, S., Arkoub, L., Madani K., 2013. Effect of solvents extraction on phenolic content and antioxidant activity of the byproduct of eggplant, Industrial Crops and Products, 49:668-674. 
Brand-Williams, W., Cuvelier, M.E., Berset, C., 1995. Use of a free-radical method to evaluate antioxidant activity. Food Science and TechnologyLebensmittel-Wissenschaft \&Technologie, 28(1):2530.

Cerezo, A.B., Cuevas, E., Winterhalter, P., GarciaParrilla, M.C., Troncoso, A.M., 2010. Isolation, identification, and antioxidant activity of anthocyanin compounds in Camarosa strawberry. Food Chemistry, 123(3):574-582.

Dorman H.J.D., Hiltunen, R., 2004. Fe (III) reductive and free radical-scavenging properties of summer savory (Satureja hortensis L.) extract and subfractions. Food Chemistry, 88(2):193-199.

Dyduch-Sieminska, M., Najda, A., Dyduch, J., Gantner, M., Klimek, K., 2015. The content of secondary metabolites and antioxidant activity of wild strawberry fruit (Fragaria vesca L.), Journal of Analytical Methods in Chemistry Article number: 831238.

Hayouni, E.A., Abedrabba, M., Bouix, M., Hamdi, M., 2007. The effects of solvents and extraction on the phenolic contents and biological activities in vitro of Tunisian Quercus coccifera L. and Juniperus phoenicea $L$. fruit extracts. Food Chemistry, 105(3):1126-1134.

Kim, Y.-J., Shin, Y., 2015. Antioxidant profile, antioxidant activity, and physicochemical characteristics of strawberries from different cultivars and harvest locations, Journal of the Korean Society for Applied Biological Chemistry, 58(4):587-595.

Marioda, A.A., Ibrahim, R.M., Ismail, M., Ismail N., 2012. Antioxidant activity of phenolic extracts from kenaf (Hibiscus Cannabinus) seedcake, Grasas y Aceites, 63(2):167-174.

Mitić, M.N., Kostić, D.A., Pavlović, A.N., Imitrijevic, D.S., Veljkovic, J.N., 2014. Effects of solvent extraction system on concentration and antioxidant activity of strawberry phenolics, Agro Food Industry $\mathrm{Hi}$-Tech, 25(5):24-28.

Oyaizu, M., 1988. Antioxidative activities of browning products of glucosamine actionated by organic solvent and thin layer chromatography. Nippon Shokuhin Kogyo Gakkaishi 35:771-775.

Peterson, J., Dwyer, J., 1998. Flavonoids: Dietary occurrence and biochemical activity. Nutrition Research, 18(12):1995-2018.

Prior, R.L., Wu, X., Schaich, K., 2005. Standardized methods for the determination of antioxidant capacity and phenolics in foods and dietary supplements. Journal of Agricultural and Food Chemistry, 53(10):4290-4302.

Re, R., Pellegrini, N., Proteggente, A., Pannala, A., Yang, M., Rice-Evans, C., 1999. Antioxidant activity applying an improved ABTS radical cation decolorization assay. Free Radical Biology and Medicine, 26(9-10):1231-1237.

Reis, B., Martins, M., Barreto, B., Milhazes, N., Garrido, E.M., Silva, P., Borges, F., 2010. Structure-property-activity relationship of phenolic acids and derivatives. Protocatechuic acid alkyl esters. Journal of Agricultural and Food Chemistry, 58(11):6986-6993.

Saini, R., Garg, V., Dangwal, K., 2013. Effect of extraction solvents on polyphenolic composition and antioxidant, antiproliferative activities of Himalyan bayberry (Myrica esculenta). Food Science and Biotechnology, 22(4):887-894.

Santas, J., Carbó, R., Gordon, M.H., Almajano, M.P., 2008. Comparison of the antioxidant activity of two Spanish onion varieties. Food Chemistry, 107(3):1210-1216.

Seal, T., Halder, N., Chaudhuri, K., Sinha S.N., 2015. Evaluation of antioxidant activities of algae and effect of solvent extraction system, International Journal of Pharmaceutical Sciences and Research, 6(3):1273-1278.

Seeram, N.P., Lee, R., Scheuller, H.S., Heber, D., 2006. Identification of phenolic compounds in strawberries by liquid chromatography electrospray ionization mass spectroscopy. Food Chemistry, 97(1):1-11.

Singleton, V.L., Rossi, J.A., 1965, Colorimetry of total phenolics with phosphomolybdic-phosphotungstic acid reagents. American Journal of Enology and Viticulture, 16:144-158.

Sun, T., Ho C.T., 2005. Antioxidant activities of buckwheat extracts, Food Chemistry, 90(4):743-749.

Ubeda, C., Callejón, R.M., Hidalgo, C., Torija, M.J., Troncoso, A.M., Morales, M.L., 2013. Employment of different processes for the production of strawberry vinegars: Effects on antioxidant activity, total phenols and monomeric anthocyanins. LWT - Food Science and Technology, 52(2):139-145.

Wang, H., Helliwell, K., 2001. Determination of flavonols in green and black tea leaves and green tea infusions by high-performance liquid chromatography. Food Research International, 34(2-3):223-227.

Wang, S.Y., Lin, H.S., 2000. Antioxidant activity in fruits and leaves of blackberry, raspberry and strawberry varies with cultivar and developmental stage. Journal of Agricultural and Food Chemistry, 48(2):140-146.

WCRF/AICR, 2007. Food, Nutrition, Physical Activity and the Prevention of Cancer: A global perspective. world cancer research fund/American institute for cancer research, Washington, DC, USA.

Wolfe, K.L., Kang, X., He, X., Dong, M., Zhang, Q., Liu, R.H., 2008. Cellular antioxidant activity of 
DOI: 10.29132/ijpas.354885

common fruits. Journal of Agricultural and Food Chemistry, 56(18):8418-8426.

Zhishen, J., Mengcheng, T., Jianming, W., 1999. The determination of flavonoid contents in mulberry and their scavenging effects on superoxide radicals. Food Chemistry, 64(4):555-559. 